\title{
Permafrost Regime Affects the Nutritional Status and Productivity of Larches in Central Siberia
}

\author{
Anatoly S. Prokushkin ${ }^{1, *}$, Frank Hagedorn ${ }^{2}$, Oleg S. Pokrovsky ${ }^{3}$, Jerome Viers ${ }^{3}$, \\ Alexander V. Kirdyanov ${ }^{1}$, Oxana V. Masyagina ${ }^{1}$, Marina P. Prokushkina ${ }^{4}$ and \\ William H. McDowell 5 it \\ 1 V.N. Sukachev Institute of Forest SB RAS, Akademgorodok 50/28, 660036 Krasnoyarsk, Russia; \\ kirdyanov@ksc.krasn.ru (A.V.K.); oxanamas@ksc.krasn.ru (O.V.M.) \\ 2 WSL, Zürcherstrasse 111, 8903 Birmensdorf, Switzerland; frank.hagedorn@wsl.ch \\ 3 GET, Université Paul Sabatier-CNRS-IRD, 14 Avenue Edouard Belin, 31400 Toulouse, France; \\ oleg.pokrovski@get.omp.eu (O.S.P.); jerome.viers@get.obs-mip.fr (J.V.) \\ 4 Siberian Federal University, Svobodny 79, 660041 Krasnoyarsk, Russia; mprokushkina@gmail.com \\ 5 Department of Natural Resources and the Environment, University of New Hampshire, Durham, NH 03824, \\ USA; bill.mcdowell@unh.edu \\ * Correspondence: prokushkin@ksc.krasn.ru; Tel.: +7-9131-782-5317
}

Received: 13 April 2018; Accepted: 31 May 2018; Published: 1 June 2018

\begin{abstract}
Permafrost exerts strong controls on forest development through nutrient availability. The key question of this study was to assess the effect of site conditions on macroelement concentration and stable isotope $\left(\delta^{13} \mathrm{C}\right.$ and $\left.\delta^{15} \mathrm{~N}\right)$ dynamics during the growing season, and nutrient stoichiometry and resorption efficiency in the foliage of two common larch species in Siberia. Foliar nutrient $(\mathrm{N}, \mathrm{P}$ and $\mathrm{K})$ concentrations of larches grown on permafrost soils were exceptionally high in juvenile needles compared to those from a permafrost-free region $(+50 \%$ and $130 \%$ for $\mathrm{P}$ and $\mathrm{K})$, but were two-fold lower at needle maturation. Within permafrost terrain trees, sites with a warmer and deeper soil active layer had $15-60 \%$ greater nutrient concentrations and higher $\delta^{15} \mathrm{~N}$ in their needles compared to shallower, colder soils. Larch of permafrost-free sites demonstrated an enrichment of foliage in ${ }^{15} \mathrm{~N}(+1.4 \%$ to $+2.4 \%)$ in comparison to permafrost terrain $(-2.0 \%$ to $-6.9 \%$ ). At all sites, foliar $\delta^{13} \mathrm{C}$ decreased from June to August, which very likely results from an increasing contribution of current photoassimilates to build foliar biomass. With senescence, nutrient concentrations in larch needles decreased significantly by $60-90 \%$. This strong ability of larch to retain nutrients through resorption is the essential mechanism that maintains tree growth early in the growing season when soil remains frozen. The high resorptive efficiency found for $\mathrm{K}$ and $\mathrm{P}$ for larches established on permafrost suggests nutrient limitation of tree growth within the Central Siberian Plateau not only by N, as previously reported, but also by $\mathrm{P}$ and $\mathrm{K}$. The increasing nutrient concentrations and a ${ }^{15} \mathrm{~N}$ enrichment of foliage towards warmer sites was paralleled by an up to 50-fold increase in biomass production, strongly suggesting that accelerated nutrient cycling with permafrost degradation contributes to an increased productivity of Siberian larch forests.
\end{abstract}

Keywords: permafrost; Siberian Larix spp.; foliar nutrients; foliar $\delta^{13} \mathrm{C}$ and $\delta^{15} \mathrm{~N}$; spatio-temporal variation; stoichiometry; nutrient resorption

\section{Introduction}

Boreal forest ecosystems store large amounts of carbon (C) in their biomass and soils and thus, changes in their $\mathrm{C}$ stocks might have large impacts on atmospheric $\mathrm{CO}_{2}$ concentrations [1]. In this context, vast larch forests across Siberia may play an important role in $C$ sequestration 
given the unique characteristics of Larix spp. [2], including its broad geographic distribution [3,4], high photosynthetic capacity [5-7], and high stand biomass under favorable conditions [2,8]. Eddy covariance measurements indicate that mature larch stands across Siberia function nowadays as a relatively weak to medium sink of atmospheric $\mathrm{CO}_{2}$ [9-11]. Temperature, water, and nutrient supply are known to be the most important abiotic variables controlling their sink strength under current conditions.

Although Larix species in continental Siberia are generally exposed to a water deficit $[6,7,10,12]$, they typically show the highest photoassimilation rates among coniferous tree species when climatic conditions are favorable, not only on a yearly basis, but also on a daily basis, which allows them to compensate for the short growing period [6]. Such a strategy, nevertheless, is associated with greater water conductance, much higher transpiration water losses [6], and lower water use efficiency (WUE) for assimilated carbon [5]. This low WUE is particularly evident in the low values of $\delta^{13} \mathrm{C}$ of foliage in comparison to co-occurring evergreen conifers [2,5]. High spatial variability of larch foliar $\delta^{13} \mathrm{C}$ among 20 locations in the Northern hemisphere [5], as well as significant seasonal changes of foliar ${ }^{13} \mathrm{C}$ within a single site [9], indicate that environmental controls of larch foliar $\delta^{13} \mathrm{C}$ and thus WUE remain uncertain.

In conjunction with high photosynthetic rates, larch species of the Northern hemisphere are characterized by the highest concentrations of nitrogen $[2,5,9,13]$ and other macronutrients (e.g., $\mathrm{P}$ and K) [13] in foliage relative to evergreen conifers, very likely due to annually renewed needles. The high nutrient demand to build foliar biomass may constrain the ability of larch taiga on permafrost soils to act as a sink of atmospheric $\mathrm{C}[14,15]$. Globally, $\mathrm{N}$ and $\mathrm{P}$ are the most common nutrients limiting plant productivity and atmospheric $C$ sequestration throughout terrestrial biomes [16-19]. In particular, $\mathrm{N}$ limitation is the most pronounced in deciduous needle-leaf forests in high-latitude regions of the Northern Hemisphere due to slow N mineralization rates [14,19]. Nitrogen concentrations and the natural isotopic abundance of $\mathrm{N}\left(\delta^{15} \mathrm{~N}:{ }^{14} \mathrm{~N}\right)$ in plant foliage integrate ecosystem biogeochemical processes involved in $\mathrm{N}$ cycling and its sources within an ecosystem $[20,21]$. In particular, foliar $\delta^{15} \mathrm{~N}$ in boreal forest ecosystems is reported to respond positively to an overall increase of $\mathrm{N}$ availability in soils, as larger soil $\mathrm{N}$ "stimulates" the loss of depleted $\mathrm{N}$ in soluble and gaseous forms and results in $\delta^{15} \mathrm{~N}$ enrichment of the remaining pool. An important mechanism to offset nutrient limitation in plants in the boreal biome is their symbiosis with fungi that is significantly changing the isotopic composition of $\mathrm{N}$ in the host plant in comparison to the bulk $\mathrm{N}$ source in soils [21]. Larix species are reported to rely on ectomycorrhyzal fungi [22] that are responsible for the most significant $\mathrm{N}$ depletion of host plant tissues [23]. All these factors might be of particular importance for permafrost terrains, where seasonal thawing of soil causes a gradual increase of soil depth (soil active layer) that is accessible for root exploration (e.g., decreasing dependence on fungal $\mathrm{N}$ ) and an uptake of isotopically distinct $\mathrm{N}$ early and late in the growing season (i.e., light $\mathrm{N}$ in topsoil vs. heavy $\mathrm{N}$ in subsoil) [24].

The resorption (retranslocation) of nutrients prior to leaf senescence is the main mechanism of nutrient preservation at the annual time scale [2,25-27], which influences whole tree survival on permafrost [28]. Indeed, nutrient retranslocation may supply a considerable part of the tree's nutrient requirements for new biomass production at the beginning of the next growing season, when the soil remains frozen. Nitrogen- and P-resorption efficiency, which is defined as the proportion of maximum nutrient pool resorbed prior to leaf abscission, ranges from 0 to $80 \%$ according to species and environmental conditions $[26,27,29]$ and is generally higher for Larix spp. in comparison to sympatric evergreen conifers [2].

Within permafrost-affected landscapes hydrology, thermal properties and biogeochemical processes of an ecosystem may strongly vary among specific sites. Sites with northern aspects receive lower insolation than those with southern aspects, resulting in cooler soils, slower soil thawing rates during the frost-free season, and a shallower active layer. Poorly-drained sites in depressions facilitate the development of forested bogs, which hampers the mineralization of plant residues and in turn, induces lower soil temperatures due to the higher insulation of soils [30]. As a consequence, forested 
bogs are nutrient-poor as they primarily rely on the atmospheric input of nutrients. Therefore, specific sites within the permafrost terrain may serve as a natural laboratory for analyzing various aspects of nutrient cycling in forest ecosystems developed on Gelisols. Ongoing climate warming in high latitudes is predicted to enhance permafrost thawing and deepening of the active layer. Because these processes clearly result in increased element turnover rates [31], the analysis of nutrient contents and dynamics in the foliar biomass of larches growing in diverse landscape units provides an excellent opportunity to study tree responses to climate warming in high-latitude permafrost regions.

The aim of this study was to estimate the effects of permafrost on the nutritional status of larch trees in Central Siberia and to assess possible responses of larch stands to projected warming at high latitudes. Our approach was to make use of a natural experimental set-up provided by the strong micrometeorological differences among sites within permafrost terrain: (i) Northern slopes with a continuous permafrost zone; (ii) adjacent south-facing stands with a deeper active layer; (iii) a fertile soil in the valley; and (iv) a forested bog, and to compare them with (v) permafrost-free sites further south. At these sites, we analyzed the seasonal dynamics of foliar concentrations of $C, N, P$, and $K$ and the stable $\mathrm{C}$ and $\mathrm{N}$ isotope composition $\left(\delta^{13} \mathrm{C}\right.$ and $\left.\delta^{15} \mathrm{~N}\right)$ of the main larch species (Larix gmelinii [Rupr.] Rupr and Larix sibirica Ledeb). Our overall hypotheses were that: (1) the nutritional status of larch trees will improve from colder to warmer sites and thus, with an increasing degradation of permafrost; (2) the improved nutrient status will be paralleled by enhanced tree growth, which would suggest that accelerated nutrient cycling with permafrost degradation contributes to an increased productivity of Siberian larch forests; and (3) with respect to seasonal nutrient dynamics, we expected a stronger nutrient resorption in permafrost than in permafrost-free terrain, which may facilitate trees to grow early in the season and under nutrient-poor conditions.

\section{Materials and Methods}

\subsection{Study Sites}

Our study sites encompass two regions in Central Siberia that differ in terms of the permafrost regime. The first site at Tura is situated in a zone of continuous permafrost (Figure 1) and the climate is cold and dry with a mean annual air temperature of $-9.1{ }^{\circ} \mathrm{C}$ (1929-2012). Mean monthly air temperature varies from about $-36{ }^{\circ} \mathrm{C}$ in January to $16.5^{\circ} \mathrm{C}$ in July. Annual precipitation in this region is $371 \mathrm{~mm}$, with $60-70 \%$ occurring during summer. In our study, we have chosen four tree stands of Gmelin's larch (Larix gmelinii [Rupr.] Rupr) near the Tura settlement in Central Siberia $\left(64^{\circ} 19^{\prime} \mathrm{N}\right.$, $\left.100^{\circ} 15^{\prime} \mathrm{E}\right)$ to represent different but typical site conditions for the Siberian landscape: south-facing slope, north-facing slope, forested Sphagnum bog, and stream valley (hereafter referred to as TS, TN, TB, and TV, respectively) (Figure 1). A detailed description of the sites was provided by Viers et al. [32] and is given in Tables 1 and 2. Larches of all sites are growing on soils that developed from basalt as parent rock, but sites varied drastically in active layer depth (Table 2). Importantly, three stands (TS, TN, and TB) were regenerated after a stand-replacing ground fire occurred in 1899, resulting in even age stand structures. Within the riparian zone (TV site), however, the same fire event did not cause the death of larch trees and the stand is composed of several generations of larch trees (uneven age stand structure). As a result of similarities in parent rock and fire history, the stand net carbon assimilation and nutrient cycling are presumably controlled by intrinsic site-specific soil hydrothermal conditions.

The second site is located in a permafrost-free region near Krasnoyarsk (Forest-steppe ecotone). Foliar nutrient dynamics were measured for two larch species (L. gmelinii and L. sibirica) growing in adjacent plantations in the arboretum of the V.N. Sukachev Institute of Forest Siberian Branch of the Russian Academy of Science (SB RAS). The mean annual air temperature at Krasnoyarsk is $0.9{ }^{\circ} \mathrm{C}$ (1891-2009). Mean monthly air temperature varies from about $-16.8^{\circ} \mathrm{C}$ in January to $19.1^{\circ} \mathrm{C}$ in July. Mean annual precipitation is $500 \mathrm{~mm}$ (1967-2009). The soil is seasonally frozen (November-April). Ground vegetation is dominated by graminoids and a considerable portion of the area is covered with larch needle litter (for stand and soil characteristics, see Tables 1 and 2). 

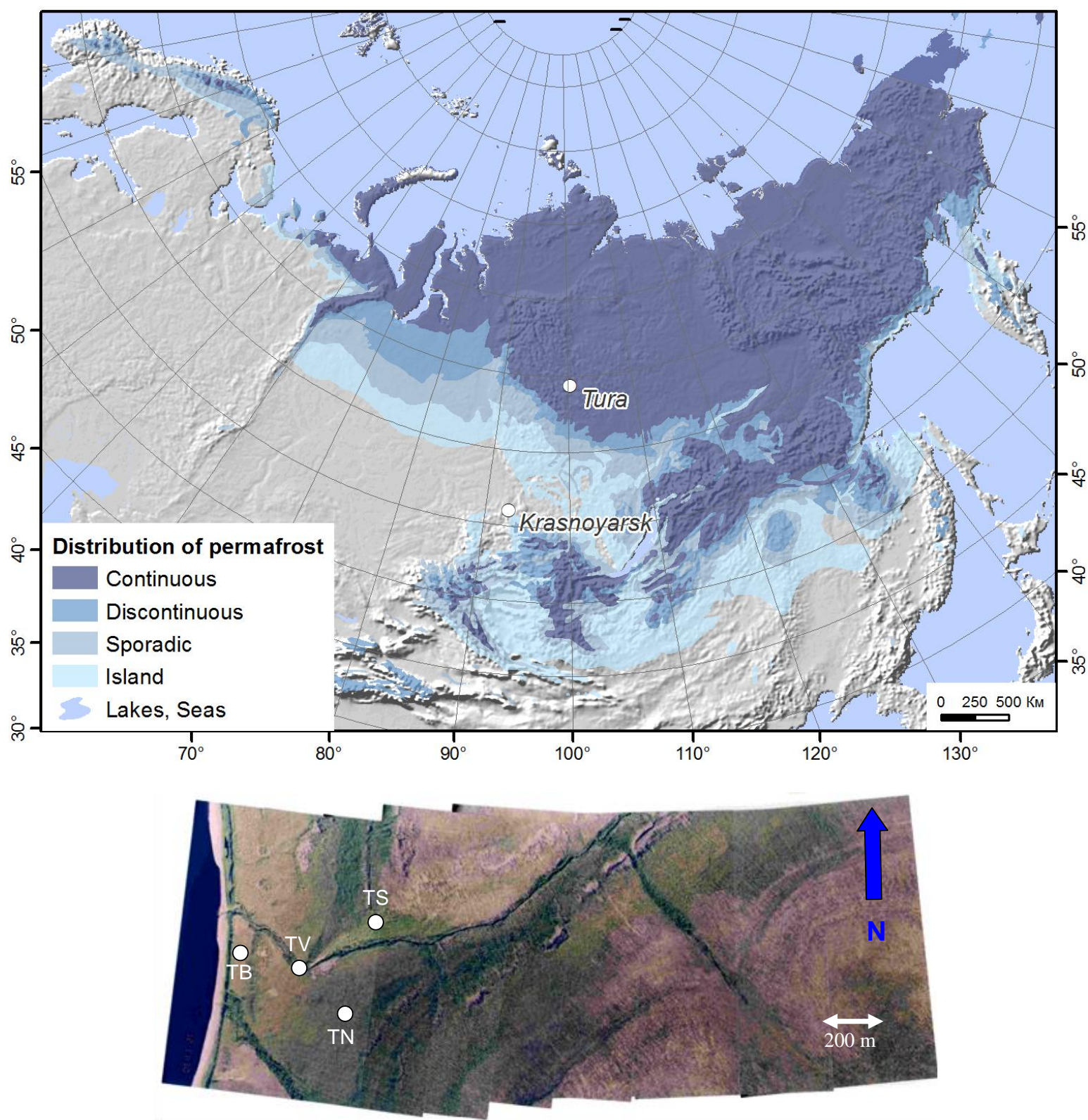

Figure 1. The map of permafrost distribution (adapted from Brown et al., 1998) and location of sites in Central Siberia. Bottom image shows the location of study sites in various habitats within permafrost terrain (Tura): TN—north-facing slope, TS—south-facing slope, TV—stream valley (riparian zone) and TB-bog. 
Table 1. Site and tree stand characteristics of the study sites in Central Siberia.

\begin{tabular}{|c|c|c|c|c|c|c|c|c|c|c|}
\hline \multirow{2}{*}{$\begin{array}{c}\text { Stand } \\
\text { Dominant }\end{array}$} & \multirow{2}{*}{ Study Site } & \multirow{2}{*}{ Latitude/Longitude } & \multirow{2}{*}{$\begin{array}{l}\text { Stand Density, } \\
\text { Tree/ha }\end{array}$} & \multirow{2}{*}{ Age, Years } & \multirow{2}{*}{$\begin{array}{l}\text { Mean Tree Ring } \\
\text { Width, mm }\end{array}$} & \multirow{2}{*}{$\mathrm{DBH}, \mathrm{cm}$} & \multirow{2}{*}{$\begin{array}{c}\text { Tree Height, } \\
\text { m }\end{array}$} & \multicolumn{3}{|c|}{ Aboveground Biomass, $\mathrm{Mg} / \mathrm{ha}$} \\
\hline & & & & & & & & Trunk & Needle & Total \\
\hline \multicolumn{11}{|c|}{ Tura: continuous permafrost terrain } \\
\hline L.gmelinii & $\begin{array}{l}\text { Sphagnum bog } \\
\text { (TB) }\end{array}$ & $\begin{array}{l}64^{\circ} 19^{\prime} 30^{\prime \prime} \mathrm{N} \\
100^{\circ} 15^{\prime} 53^{\prime \prime} \mathrm{E}\end{array}$ & 2480 & 86 & $0.11 \pm 0.05$ & 4.0 & 4.1 & 5.6 & 0.3 & 7.0 \\
\hline L.gmelinii & $\begin{array}{l}\text { North-facing } \\
\text { slope (TN) }\end{array}$ & $\begin{array}{l}64^{\circ} 19^{\prime} 21^{\prime \prime} \mathrm{N} \\
100^{\circ} 14^{\prime} 53^{\prime \prime} \mathrm{E}\end{array}$ & 4400 & 99 & $0.11 \pm 0.03$ & 5.8 & 7.7 & 26.9 & 0.5 & 28.2 \\
\hline L. gmelinii & $\begin{array}{l}\text { South-facing slope } \\
\text { (TS) }\end{array}$ & $\begin{array}{l}64^{\circ} 19^{\prime} 32^{\prime \prime} \mathrm{N} \\
100^{\circ} 15^{\prime} 32^{\prime \prime} \mathrm{E}\end{array}$ & 2700 & 91 & $0.17 \pm 0.05$ & 9.3 & 11.3 & 52.3 & 1.6 & 56.6 \\
\hline L. gmelinii & $\begin{array}{l}\text { Riparian zone } \\
\text { (TV) }\end{array}$ & $\begin{array}{l}64^{\circ} 19^{\prime} 29^{\prime \prime} \mathrm{N} \\
100^{\circ} 15^{\prime} 07^{\prime \prime} \mathrm{E}\end{array}$ & 1100 & 156 & $0.51 \pm 0.20$ & 15.0 & 12.9 & 55.9 & 7.0 & 79.0 \\
\hline \multicolumn{11}{|c|}{ Krasnoyarsk: permafrost-free terrain } \\
\hline L. gmelinii & $\begin{array}{l}\text { Common garden } \\
\text { (L.g. KD) }\end{array}$ & $55^{\circ} 59^{\prime} \mathrm{N} 92^{\circ} 45^{\prime} \mathrm{E}$ & 760 & 32 & $3.55 \pm 2.56$ & 17.5 & 14.8 & 38.6 & 7.7 & 70.5 \\
\hline L. sibirica & $\begin{array}{l}\text { Common garden } \\
\text { (L.s. KD) }\end{array}$ & $55^{\circ} 59^{\prime} \mathrm{N} 92^{\circ} 45^{\prime} \mathrm{E}$ & 800 & 32 & $3.58 \pm 2.50$ & 24.0 & 16.3 & 42.0 & 6.2 & 76.3 \\
\hline
\end{tabular}

Table 2. Soil characteristics of sites in Tura (permafrost region) and Krasnoyarsk (permafrost-free region). Data presented as mean ( \pm SD).

\begin{tabular}{|c|c|c|c|c|c|c|c|c|c|c|c|c|c|c|c|}
\hline \multirow{3}{*}{$\begin{array}{l}\text { Study Site } \\
\text { ID }\end{array}$} & \multirow{3}{*}{ Soil Type * } & \multicolumn{4}{|c|}{ Organic Layer } & \multicolumn{10}{|c|}{ Mineral Soil } \\
\hline & & \multirow{2}{*}{$\begin{array}{l}\mathrm{OC} \\
\mathrm{kg} / \mathrm{m}^{2}\end{array}$} & \multirow{2}{*}{$\frac{\delta^{13} \mathrm{C}}{\% 0}$} & \multirow{2}{*}{$\begin{array}{c}\mathrm{N} \\
\mathrm{g} / \mathrm{m}^{2}\end{array}$} & \multirow{2}{*}{$\frac{\delta^{15} \mathbf{N}}{\%}$} & \multirow{2}{*}{$\begin{array}{c}\mathrm{OC} \\
\mathrm{kg} / \mathrm{m}^{2}\end{array}$} & \multirow{2}{*}{$\frac{\boldsymbol{\delta}^{13} \mathbf{C}^{\circledR}}{\%}$} & \multirow{2}{*}{$\begin{array}{c}\mathrm{N} \\
\mathrm{g} / \mathrm{m}^{2}\end{array}$} & \multirow{2}{*}{$\frac{\delta^{15} \mathbf{N}^{\circledR}}{\% 0}$} & \multicolumn{4}{|c|}{ Active Layer Depth, cm } & \multirow{2}{*}{$\begin{array}{c}\mathrm{T}_{5 \mathrm{~cm}} \& \\
{ }^{\circ} \mathrm{C}\end{array}$} & \multirow{2}{*}{$\begin{array}{c}\text { Rooting } \\
\text { Depth ** }\end{array}$} \\
\hline & & & & & & & & & & June & July & August & Sept & & \\
\hline \multicolumn{16}{|c|}{ Tura: continuous permafrost terrain } \\
\hline $\mathrm{TN}$ & Typic Aquiturbel & 2.1 & -28.35 & 54 & -0.20 & 6.6 & -27.12 & 307 & 3.24 & $1 \pm 1$ & $25 \pm 12$ & $36 \pm 11$ & 42 & 2.8 & 12 \\
\hline TS & Typic Haplocryept & 0.8 & -29.04 & 22 & -1.14 & 5.4 & -27.47 & 309 & 3.43 & $18 \pm 8$ & $86 \pm 15$ & $112 \pm 26$ & 123 & 6.6 & 64 \\
\hline TВ & Sphagnic Fibristel & 6.4 & -28.64 & 96 & 0.19 & 5.5 & -28.02 & 425 & 1.58 & 0 & $1 \pm 2$ & $15 \pm 8$ & 20 & 0.1 & 0 \\
\hline TV & Lithic Aquorthel & 1.8 & -29.67 & 60 & -0.06 & 7.3 & -28.21 & 365 & 2.31 & $5 \pm 2$ & $52 \pm 16$ & $63 \pm 19$ & 88 & 4.1 & 45 \\
\hline \multicolumn{16}{|c|}{ Krasnoyarsk: permafrost-free terrain } \\
\hline L.g. KD & Typic Haplocryalf & 0.4 & - & 16 & - & 2.9 & - & 251 & - & - & - & - & - & 9.2 & 70 \\
\hline L.s. KD & Typic Haplocryalf & 0.3 & - & 17 & - & 3.2 & - & 342 & - & - & - & - & - & 8.9 & 62 \\
\hline
\end{tabular}

${ }^{*}$ Keys to soil taxonomy (1998); ${ }^{\circledR}$ Topsoil layer $(0-10 \mathrm{~cm}) ;{ }^{\wedge}$ At the date of needle collection; ${ }^{\&}$ Mean summer (June-August) soil temperature at $5 \mathrm{~cm}$ depth for two consecutive years (2005-2006); ${ }^{* *}$ the rooting depth in mineral soil. 


\subsection{Sampling and Analyses}

\subsubsection{Stand Inventory and Tree Biomass Measurements}

In mid-August of 2006, we established inventory plots at all sites as reported in [33] according to the Russian inventory method [34]. However, we modified the original method by increasing the number of trees from 100 to more than 200 trees per plot, thereby enlarging the plot sizes. Taking into account the different densities of trees, plot areas varied from roughly 200 to $1800 \mathrm{~m}^{2}$. For every tree on the plot, we measured the tree height, D0, DBH (the diameters at zero height and at breast height), and crown length and assessed whether the tree was living or dead. To estimate the stand level total aboveground biomass and biomass of its fractions (stem, branches, and needles), we applied allometric equations based on destructively sampled model trees. For this purpose, at every site, seven to 15 trees from each diameter class (1-2 cm step) were logged and fresh biomass of the trunk and crown (branches with needles) was weighed separately. Then, subsamples of trunk (wood discs from D0, DBH, 2/3 and 3/4 height), in addition to thick $(>2 \mathrm{~cm})$ and thin $(<2 \mathrm{~cm})$ branches and needles, were sampled from the bottom, middle, and top part of each crown (three mean branches) and dried at $105{ }^{\circ} \mathrm{C}$ in the oven, from which we obtained dry weight conversion coefficients for each biomass fraction. Site-specific allometric equations were developed relating component biomass to diameter at breast height $(\mathrm{DBH})$ and tree height $(\mathrm{h})\left(\mathrm{Y}=\mathrm{a} \mathrm{X}^{\mathrm{b}}\right.$, where $\mathrm{Y}$-biomass, $\mathrm{X}-\mathrm{DBH}$ or $\left.\mathrm{h}\right)$. Diameter at breast height showed the best predictions of biomass in all plots $\left(R^{2}>0.96\right.$ for total and trunk biomass, $\mathrm{R}^{2}>0.69$ for needles). Finally, the site- and fraction-specific allometric equations were used to calculate the total aboveground biomass and fractions (Supplementary Materials, Table S1). The production rate of stem biomass was calculated by first estimating the DBH increment from the mean tree ring widths of the last five years prior to the collection year (2001-2005) and then applying the allometric equations.

Tree stand age and mean tree ring width (TRW) were determined by analyzing wood discs and cores of at least 20 trees using dendrochronological methods [35]. Fire year (1899) was also estimated dendrochronologically by dating the fire scars of discs from two to five trees that survived the fire at every site.

\subsubsection{Soils}

Samples of the organic layer and mineral soil were collected along a 10-m transect at the centre of each plot. The soil active layer depth (ALD) (annually thawed depth to permafrost) and surficial organic layer column (moss-lichen stratum and organic soil layer) were measured by a steel rod every $1 \mathrm{~m}(n=11)$. To measure stocks of organic layer, we sampled five columns (area $100 \mathrm{~cm}^{2}$ ) every $2 \mathrm{~m}$. Collected material was separated into the living portion of ground vegetation and the organic soil layer $(\mathrm{O})$. Subsamples of both portions were oven dried $\left(105^{\circ} \mathrm{C}\right)$ for $48 \mathrm{~h}$ to determine the ratio between the moss-lichen stratum and organic soil layer, and bulk densities. Then, the linear regression model between the respective stock and thickness of the organic layer was used to calculate the mean transect-specific organic layer stock.

Sampling of mineral soil was conducted in five soil pits at $10 \mathrm{~cm}$ depth intervals for the entire active layer down to the permafrost table $(20-120 \mathrm{~cm})$. Samples were taken in triplicate from every $10 \mathrm{~cm}$ layer using a $100 \mathrm{~cm}^{3}$ steel cylinder and then bulked. The rooting zone was determined as the maximum depth at which larch roots appeared in mineral soil. Under field conditions, all fresh soils were sieved through a 2-mm mesh sieve followed by the removal of fine roots in the $2 \mathrm{~mm}$ fraction. In parallel, one cylinder sample was taken to obtain the soil bulk density by oven drying at $105^{\circ} \mathrm{C}$ for $48 \mathrm{~h}$. For the determination of carbon (C) and nitrogen (N) concentrations, aliquots of the $2 \mathrm{~mm}$ soil fraction and bulk organic layer samples were finely ground (mixer mill, Retsch, Germany) and oven dried at $80{ }^{\circ} \mathrm{C}(48 \mathrm{~h})$. Total mass-based concentrations of $\mathrm{C}$ and $\mathrm{N}$ were measured by Cu-O catalysed dry combustion at $900{ }^{\circ} \mathrm{C}$ with $\leq 0.5 \%$ precision for standard substances (Elementar Vario Maxi CHNS analyser, Elementar Analysensysteme $\mathrm{GmbH}$, Hanau, Germany). Carbonate $\mathrm{C}$ was not detected in any of the soils. The isotope ratios $\left(\delta^{13} \mathrm{C}\right.$ and $\left.\delta^{15} \mathrm{~N}\right)$ were determined on soil samples (organic $(\mathrm{O})$ 
layer and humic (A) horizons) collected in 2011 in the same sites using a Delta-S isotope ratio mass spectrometer (Finnigan MAT, Bremen, Germany) linked to an elemental analyzer (EA-1108, Carlo Erba, Cornaredo, Italy) via a variable open split interface (ConFlo-II; Finnigan MAT, Bremen, Germany) at the Max-Planck Institute for Biogeochemistry (Jena, Germany). The $\delta^{13} \mathrm{C}$ and $\delta^{15} \mathrm{~N}$ were determined in continuous flow mode. This guarantees a high sample throughput rate with good precision for $\delta^{13} \mathrm{C}$ $(\mathrm{r} \pm 0.1 \%)$ and $\delta^{15} \mathrm{~N}(\mathrm{r} \pm 0.2 \%)$. The isotopic values were expressed in the $\delta$ notation relative to the international standards (Equation (1)):

$$
\delta_{\text {sample }}=\left(\mathrm{R}_{\text {sample }} / \mathrm{R}_{\text {standard }}-1\right) \times 1000
$$

where $R_{\text {sample }}$ is the molar fraction of ${ }^{13} \mathrm{C} /{ }^{12} \mathrm{C}$, or the ${ }^{15} \mathrm{~N} /{ }^{14} \mathrm{~N}$ ratio of the sample and $\mathrm{R}_{\text {standard }}$ of the standards Vienna Pee Dee belemnite for $\mathrm{C}$ and atmospheric $\mathrm{N}_{2}$ for $\mathrm{N}$.

Values of total $\mathrm{C}$ and $\mathrm{N}$ were normalized to the absolute dry mass of soil (after drying at $105^{\circ} \mathrm{C}$ ). Further, the bulk density of soil and $\mathrm{C}$ and $\mathrm{N}$ mass-based concentrations were used to calculate $\mathrm{C}$ and $\mathrm{N}$ stocks in the organic and mineral soil. In the latter case, the depth was limited to $0.5 \mathrm{~m}$ for comparisons among sites that varied greatly in active layer depth $(20-120 \mathrm{~cm})$.

To estimate leaf carbon isotopic discrimination $\left(\Delta_{\text {leaf }}\right)$ as a measure for water use efficiency (WUEi) using the equation of Farquar et al. [36], we took mean $-7.7 \%$ as the $\delta^{13} \mathrm{C}$ value in atmospheric $\mathrm{CO}_{2}$ obtained in the Zotino tall tower observatory (ZOTTO, $60^{\circ} \mathrm{N}, 90^{\circ} \mathrm{E}$ ) for June-August of 2008-2010 $(\mathrm{SD}=0.3 \%$, range -8.5 to $-7.1 \%$ ).

\subsubsection{Larch Needles}

Samples of larch needles were collected during the growing season of 2006, taking into account the differences in phenology between the sites located in northern and southern parts of Central Siberia. Needles were sampled four times: (1) in a juvenile state on 7 June at Tura (60 $\pm 4 \%$ of maximum mass and $73 \pm 6 \%$ of the length attained in July) and on 25 May at Krasnoyarsk ( $66 \pm 5 \%$ of maximum mass and $81 \pm 3 \%$ of length attained in August); (2) as mature needles (18 and 21 July, respectively at Tura and Krasnoyarsk); (3) as senescing needles (23 and 25 August); and (4) finally in the coloured phase (yellow) just during needle shedding (12 September and 20 October). Samples of larch short shoot needles were collected on every plot from three to five mid-crown branches of three trees representing the mean tree size of the stand (diameter at breast height and tree height) and similar live status (crown development). In total, we collected 5-10 g of fresh needles from every tree at each sampling occasion.

After collection, the plant material was first cleaned on site with ultrapure water to remove surface particles, air dried, and stored in clean plastic bags. Back in the laboratory, samples were dried at $80{ }^{\circ} \mathrm{C}$ for $48 \mathrm{~h}$ and finely ground using a mixer mill (Retsch, Haan, Germany). Total mass-based concentrations of $\mathrm{C}$ and $\mathrm{N}$ and isotope ratios $\left(\delta^{13} \mathrm{C}\right.$ and $\left.\delta^{15} \mathrm{~N}\right)$ in bulk samples of larch needles were measured by the same method as for the soil samples. For the analysis of phosphorus and potassium, samples were processed in a clean room (class A 10000, [32]). Between 100 and $200 \mathrm{mg}$ of needle material was first digested in hydrogen peroxide $\left(\mathrm{H}_{2} \mathrm{O}_{2}\right)$ for $24 \mathrm{~h}$ at ambient temperature and further digested in $\mathrm{HNO}_{3}+\mathrm{HF}$, for $36 \mathrm{~h}$ at $80{ }^{\circ} \mathrm{C}$, then in $\mathrm{HCl}$ for $36 \mathrm{~h}$ at $80^{\circ} \mathrm{C}$, and finally, by $\mathrm{HCl}-\mathrm{HNO}_{3}$ treatment for $36 \mathrm{~h}$ at $80^{\circ} \mathrm{C}$. Measurements of $\mathrm{P}$ and $\mathrm{K}$ were conducted by ICP-MS (Agilent $7500 \mathrm{CE}$, Agilent Corporation, Santa Clara, CA, USA) using three-point calibration against a standard solution of a known concentration [32]. Indium and rhenium were used as internal standards to correct for instrumental drift and eventual matrix effects. The international geostandards Apple Leaves SRM 1515 (from National Institute of Standards and Technology (NIST), Gaithersburg, MD, USA), lichens BCR-CRM 482 (from BCR, Geel, Belgium), and Pine Needles SRM 1575a (from NIST, USA) were used to control the efficiency of both the acid digestion protocol and the analysis. Data presented here are within $10 \%$ of deviation of recommended values for these international standards. 


\subsection{Statistical Analyses}

The resorption efficiency was calculated as Equation (2):

$$
\% R E=\left(N_{\text {gree }}-\mathrm{N}_{\text {sen }}\right) \times 100 / \mathrm{N}_{\text {gree }}
$$

where $\mathrm{N}_{\text {green }}$ is the concentration of a nutrient in green needles collected before senescence in August, and $\mathrm{N}_{\text {sen }}$ is the nutrient concentration in senescent needles.

The effects of active layer depth (ALD) on foliar nutrient, isotopic composition, above-ground biomass, and productivity of the L. gmelinii stands were assessed with linear mixed-effects models fitted with Restricted Maximum Likelihood (lme function of the nlme package, R 3.4.0, R Core Team, 2017). We fitted the site and tree as random effects and the active layer depth and date (Julian day of the year) as fixed effects. To account for repeated measurements, we included the corAR1 function in the model with a first-order autoregressive covariate structure. Since the Krasnoyarsk site is outside the permafrost zone, we used a permafrost depth of $500 \mathrm{~cm}$ in the statistical model. Normal distribution of the residuals was investigated by visual inspection of the normal probability plots and a Shapiro-Wilk test. Differences among individual sites and between dates were estimated by a $t$-test at the $p<0.05$ level (Supplementary Materials, Table S2). Response variables and active layer depth were $\log$ transformed to meet assumptions of normality of the residuals and homogeneity of variances.

Data are shown as the mean standard deviation of three replicates. Linear regression analysis was performed to examine the relationships between soil site characteristics, foliar mass-based nutrient concentrations, isotopic composition, and carbon isotope discrimination.

\section{Results}

\subsection{Tree and Soil Parameters}

The stand biomass of larch tress at the permafrost affected site at Tura increased with soil active layer depth (Table $1 ; p<0.05$ ). Mean diameter, mean height, and total biomass of the young larch stand at the permafrost-free site (32 years; site L.S. KD) were similar to the 156-year old intrinsically nutrient-rich riparian zone (TV) in the permafrost terrain. Consequently, stand productivity increased with active layer depth and reached the greatest values at the permafrost-free site ( $p_{\text {ALD }}<0.002$; Figure 2). Greater productivity of larch species in the permafrost-free environment is also evident from the 7- to 32-fold higher mean tree ring width (TRW) for both Larix species in Krasnoyarsk in comparison to larch trees of permafrost-affected plots. In the permafrost terrain at Tura, larch stands of a similar age also demonstrated variation among sites. Mean tree diameter (DBH), height, and tree-ring width differed, being about three-fold greater in the riparian zone (TV) than in the bog (TB, Table 1). Stands grown on the slopes (TN and TS) were intermediate between those extremes, with south-facing slopes showing a higher growth of larch trees than north-facing slopes. Aboveground stand biomass had an even larger range among sites ( $>10$-fold), i.e., $7-79 \mathrm{Mg} /$ ha for total above ground biomass and $0.3-7.0 \mathrm{Mg} / \mathrm{ha}$ for foliar biomass. All biomass components increased significantly with active layer depths ( $p<0.01$; Figure 2a).

Carbon and nitrogen stocks in the upper $0.5 \mathrm{~m}$ of soil in different sites ranged from 3.3 to $11.9 \mathrm{~kg} \mathrm{C} / \mathrm{m}^{2}$ for total C and 0.3 to $0.5 \mathrm{~kg} \mathrm{~N} / \mathrm{m}^{2}$ for total $\mathrm{N}$ (Table 2), with a close positive correlation between $\mathrm{C}$ and $\mathrm{N}(r=0.92, p<0.05)$. The greatest stocks existed in permafrost terrain reaching $11.9 \mathrm{~kg} \mathrm{C} / \mathrm{m}^{2}$ and $0.5 \mathrm{~kg} \mathrm{~N} / \mathrm{m}^{2}$, respectively, in the soil of the TB site. The distribution of soil C and $\mathrm{N}$ between organic and mineral soil layers showed an increasing contribution of organic layer stocks with an increasing severity of hydroclimatic conditions. In the bog soil (TB), the organic layer comprised more than $50 \%$ and $18 \%$ of the total $\mathrm{C}$ and $\mathrm{N}$ stocks.

Soil $\delta^{15} \mathrm{~N}$ increased with soil depth and differed among sampled sites from +0.2 to $-1.2 \%$ in organic layers and +1.6 to $+3.4 \%$ in mineral topsoil layers $(0-10 \mathrm{~cm})$. Soil $\delta^{13} \mathrm{C}$ did not vary among 
sites, but increased slightly from the organic layer (variation from -28.3 to $-29.7 \%$ ) to the upper $10 \mathrm{~cm}$ of mineral soil ( -27.1 to $-28.2 \%)$.

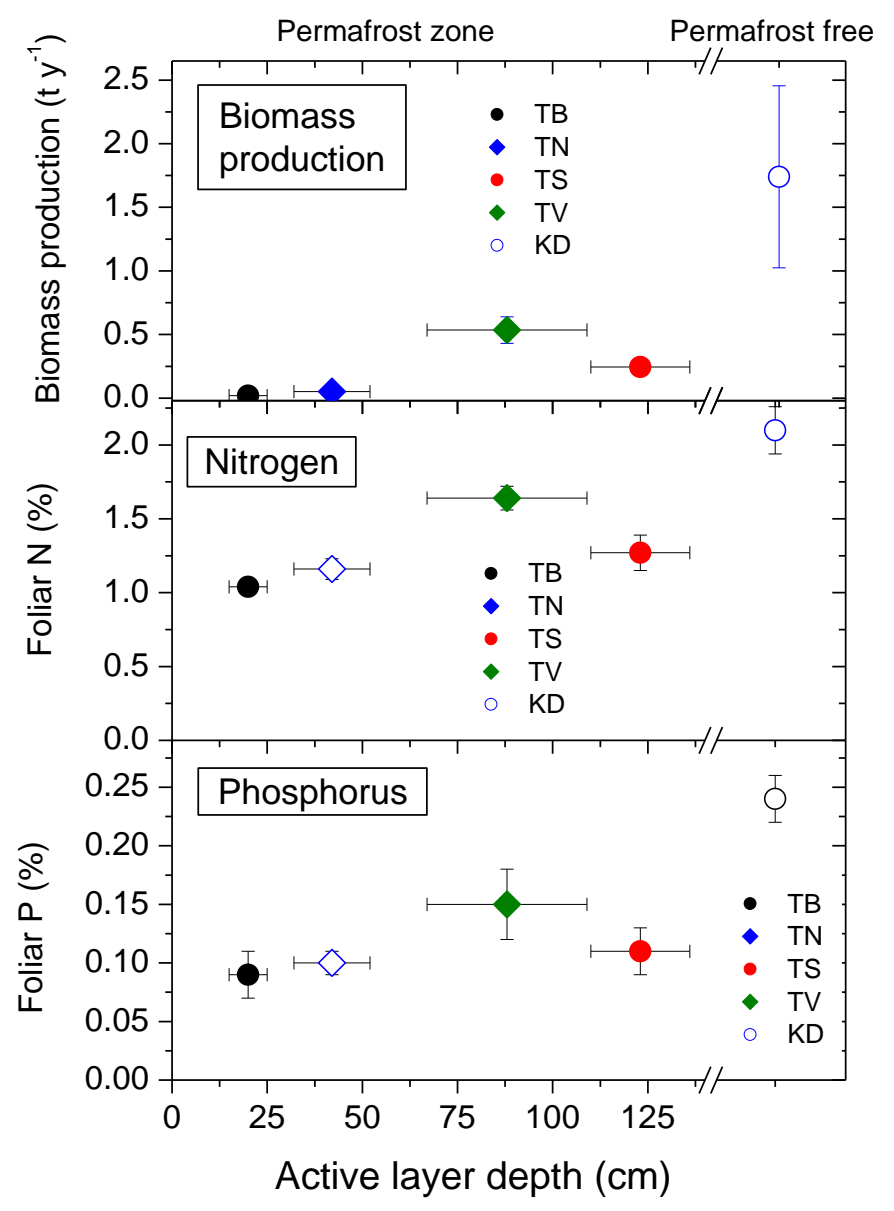

Figure 2. Stand-specific stem biomass production rates of Larix gmelinii trees for the last five years prior to collection year, and foliar $\mathrm{N}$ and $\mathrm{P}$ concentrations in mature needles (August) in relation to soil active layer depth of the four sites of the permafrost terrain and permafrost-free site. Mean and standard deviation of three replicates.

\subsection{Seasonal Dynamics of Foliar Element Concentrations and Stable Isotope Composition}

Needles of larch species at both sites showed relatively similar seasonal patterns in C concentrations (Figure 3a) with a peak in August (46.7-48.7\%), followed by lower concentrations prior to abscission. The annual net gain of $\mathrm{C}$ in foliage calculated for individual trees (based on allometric equations) ranged from $0.11 \pm 0.05 \mathrm{~kg} \mathrm{C} /$ tree in the TB to $2.17 \pm 0.59 \mathrm{~kg} \mathrm{C} /$ tree in the TV. At the stand level, assimilated $\mathrm{C}$ in foliar biomass varied from 0.15 in $\mathrm{TB}$ to $3.40 \mathrm{t} \mathrm{C} / \mathrm{ha}$ in $\mathrm{TV}$ and reached $3.70 \mathrm{tC} /$ ha in the permafrost-free terrain.

The $\delta^{13} \mathrm{C}$ values of larch foliage were highest in juvenile needles and decreased throughout the growing season in both permafrost and permafrost-free terrains, except for the riparian site TV $\left(p_{\text {time }}<0.001\right.$; Figure $3 \mathrm{~b}$ ). Maximum depletion in heavy isotope during the season was up to $2-2.4 \%$, which was characteristic for the colder sites $\mathrm{TN}$ and $\mathrm{TB}$, with $\delta^{13} \mathrm{C}$ values ranging from $-28.1 \%$ in June to $-30.4 \%$ in September $\left(p_{\mathrm{ALD} \times \text { time }}<0.002\right)$. Carbon isotopic discrimination in juvenile larch foliage showed little variation among permafrost habitats $(21.2 \% 0 \pm 0.4 \%)$, but increased during the growing season by $1.5-2 \%$, as compared to ca. $1.2 \%$ enrichment of atmospheric $\mathrm{CO}_{2}$ throughout the growing season. In August, "colder" sites (TN and TB) had generally higher $\Delta_{\text {leaf: }}:(23.3 \% \pm 0.2 \%$ ) compared to "warm" sites TS and TV $(22.0 \pm 0.4 \%)$. 

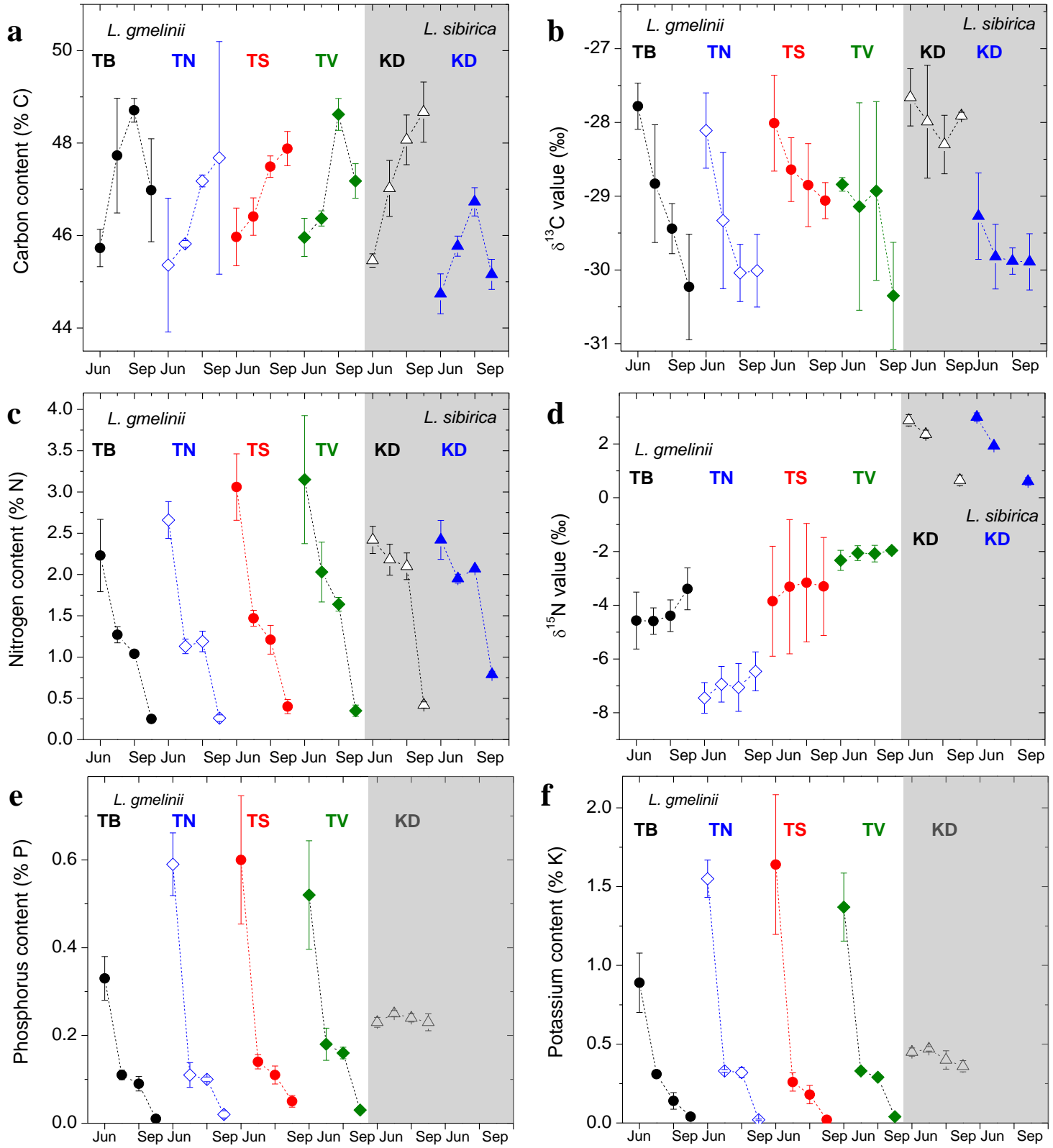

Figure 3. Seasonal dynamics of mean contents of carbon (a), carbon stable isotope compositon $\delta^{13} \mathrm{C}$ (b), nitrogen (c), nitrogen stable isotope composition $\delta^{15} \mathrm{~N}(\mathbf{d})$, phosphorus content (e) and potassium content (f) in needles of two larch species (L.g.-Larix gmelinii, L.s. - Larix sibirica) from a permafrost site (Tura: TB-bog; TN—north-facing slope, TS—south-facing slope, TV—riparian zone) and from a permafrost-free site (Krasnoayrsk: KD). Means of tree replicate trees for different dates of sampling based on phenological differences at Tura and Krasnoyarsk.

Mass-based macronutrient (N, P and K) concentrations of larch needles also showed a typical seasonal pattern $\left(p_{\text {time }}<0.001\right.$; Figure $\left.3 c, e, f\right)$, which was more pronounced at the permafrost sites. Here, nutrient concentrations in larch needles decreased by a factor of two to nine from the early season until July and August $(p<0.01)$. "Warmer" sites in the permafrost zone had generally higher early season macronutrient concentrations in needles $(31 \pm 0.8 \mathrm{mg} \mathrm{N} / \mathrm{g}, 6.0 \pm 1.5 \mathrm{mg} \mathrm{P} / \mathrm{g}$ and $16.0 \pm 1.4 \mathrm{mg} \mathrm{K} / \mathrm{g}$ d.w.) than larch trees growing at TB $(22 \pm 0.4 \mathrm{mg} \mathrm{N} / \mathrm{g}, 3.3 \pm 0.5 \mathrm{mg} \mathrm{P} / \mathrm{g}$ and $8.9 \pm 1.9 \mathrm{mg} \mathrm{K} / \mathrm{g}$ d.w.) $(p<0.01)$. In comparison to the permafrost site, seasonal changes of nutrient contents at the permafrost-free soils (Krasnoyarsk) were negligible for $\mathrm{P}$ and $\mathrm{K}$, and only a 10\% reduction was observed for $\mathrm{N}\left(P_{\mathrm{ALD} \times \text { time }}<0.001\right.$ for $\mathrm{P}$ and $\left.\mathrm{K}\right)$. As a result, the mid-summer nutrient contents in needles of Tura 
larches on permafrost are around $50 \%$ lower than values found in trees growing on permafrost-free soils (Figure $2 \mathrm{~b}, \mathrm{c} ; P_{\mathrm{ALD}}<0.05$ for $\mathrm{N}$ and $\mathrm{P}$ ).

On a stand level, N, P, and K allocated in the foliage of trees in permafrost-affected stands ranged drastically among sites and increased with active layer depth $\left(p_{\mathrm{ALD}}<0.05\right.$; Figure 4$)$. The largest pools of nutrients in foliar biomass were found in the permafrost-free terrain, following the order $\mathrm{TB}<\mathrm{TN}<\mathrm{TS}<\mathrm{TV}<\mathrm{KD}$ (Figure 4 ).

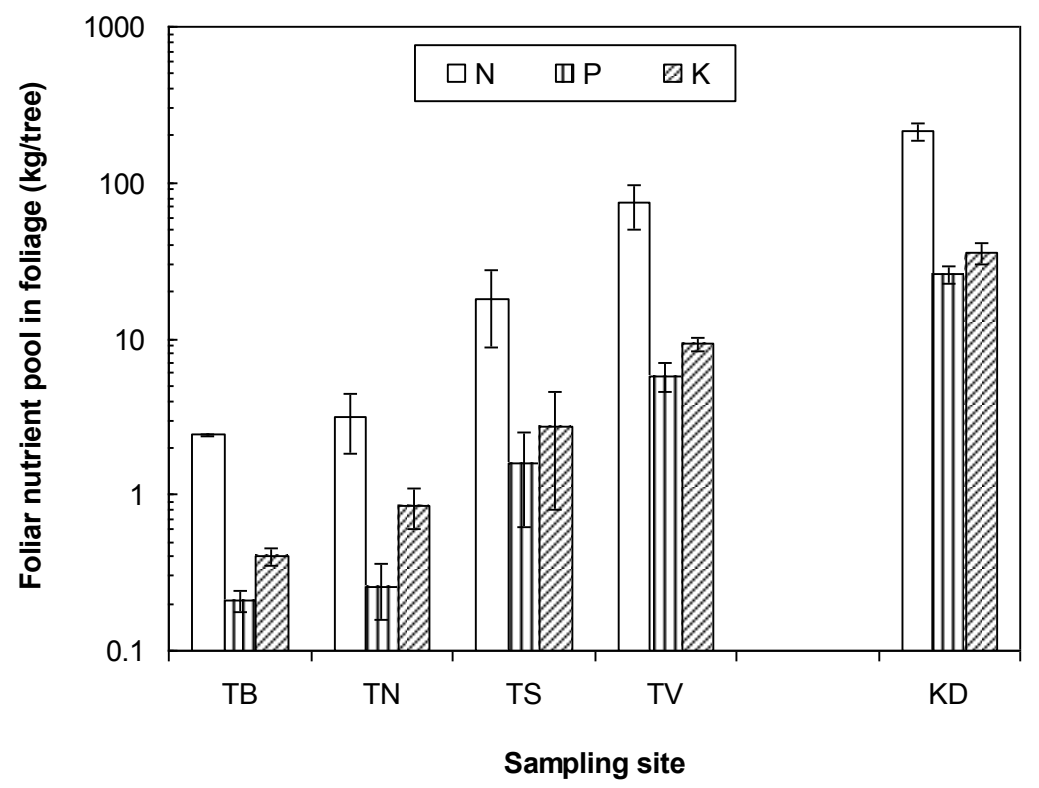

Figure 4. Nutrient pool/annual recruitment of major nutrients (N, P, and $\mathrm{K})$ in foliar biomass of Gmelin's larch in permafrost-affected (TB, TN, TS, and TV) and permafrost-free sites (KD). Means and standard deviation of three replicates.

Foliar nitrogen stable isotope ratios $\left(\delta^{15} \mathrm{~N}\right)$ showed little temporal variation during the growing season. However, they differed by as much as $9 \%$ among sites (Figure $3 \mathrm{~d}$ ) and showed a positive relation to active layer depth $\left(p_{\mathrm{ALD}}<0.001\right)$. While the needles of the permafrost-free site had positive $\delta^{15} \mathrm{~N}$ values of $+2 \%$ in both Larix species, larches growing in the TN and the TB plots had values of $-7.0 \%$ and $-5.0 \%$, respectively.

The C-to-N, N-to-P, and C:N:P ratios from permafrost sites showed an opposite pattern compared to concentrations of macronutrients. Elemental ratios were relatively narrow at the beginning of the growing season, though a two-fold higher C:N:P ratio was observed in needles of TB compared to other sites in permafrost terrain (Table 3). The C:N ratio ranged from ca. 15 in TS and TV to 18 and 22 in TN and TB, respectively $(p<0.01)$. The $\mathrm{N}: \mathrm{P}$ ratio of juvenile needles differed among sites from 4.7 in the TN site to 6.8 in the TB, with intermediate values shown for TS and TV sites. In comparison to these values, Gmelin's larch from Krasnoyarsk showed an N:P ratio of 11 and C:N of 19 at the same developmental stage. The N:P ratio increased during the growing season (up to $12.0 \pm 0.2$ in August), and showed surprisingly low variation among the sites. L. gmelinii from the permafrost-free site showed an opposite trend, with the N:P ratio decreasing from 11.1 (May) to 8.3 (August). Overall, N:P ratios decreased significantly with active layer thickness $(p<0.01)$. The C:N:P ratio changed among the compared sites in mid-season. Within the permafrost region, needles from nutrient-poor and cold sites such as TN and TB had generally larger C:N:P ratios (Table 3) in the middle of the growing season compared to 'warmer' sites TS and TV. In comparison, at the Krasnoyarsk site, the C:N:P ratio in Gmelin's larch foliage was substantially more narrow, which reflects a slight enrichment of $\mathrm{N}$ and $\mathrm{P}$ in the mature foliage (Table 3). 
Table 3. Seasonal dynamics of the C:N:P ratio in the foliage of L. gmelinii from different sites in permafrost and permafrost-free terrain.

\begin{tabular}{|c|c|c|c|c|c|c|}
\hline \multicolumn{5}{|c|}{ Permafrost-Affected Plots } & \multicolumn{2}{|r|}{ Permafrost-Free Plot } \\
\hline Date of Sampling & ТВ & TN & TS & TV & Date of Sampling & L.g. KD \\
\hline 07.06 .2006 & 144:6.8:1 & $77: 4.7: 1$ & $78: 5.4: 1$ & $71: 4.8: 1$ & 31.05 .2006 & 209:11.1:1 \\
\hline 18.07.2006 & 440:11.7:1 & $421: 10.5: 1$ & $327: 10.3: 1$ & 293:13.4:1 & 20.07 .2006 & 190:8.8:1 \\
\hline 23.08 .2006 & $557: 11.9: 1$ & 493:12.1:1 & 451:12.0:1 & $335: 11.3: 1$ & 25.08 .2006 & $190: 8.3: 1$ \\
\hline 12.09.2006 & $4566: 24.8: 1$ & 3227:18.0:1 & 1020:8.4:1 & 1236:8.9:1 & 20.10 .2006 & 194:1.7:1 \\
\hline
\end{tabular}

Senescing needles showed an abrupt reduction of mass-based nutrient concentrations in comparison to the preceding sampling in August, but demonstrated a positive correlation with green tissues ( $r=0.97$ and 0.96 for $\mathrm{N}$ and $\mathrm{P}$, respectively, $p<0.01$ ). Analysis of species-specific nutrient resorption revealed that needles of $L$. gmelinii exhibited higher retranslocation of $\mathrm{N}$ to stem/branches prior to senescence when compared with L. sibirica ( $80 \%$ vs. $62 \%$, respectively, $p<0.05)$ growing in the same plantation (Figure 5). The intra-species variation of resorption of L. gmelinii demonstrated smaller values at the permafrost than at the permafrost-free sites. While there was only a negligible resorption of $\mathrm{P}$ and $\mathrm{K}$ in senesced needles at the permafrost-free site, L. gmelinii showed a significant $(p<0.01)$ withdrawal of both P (53-88\%) and K (74-95\%) at the permafrost-affected sites (Figure 5; $p<0.01)$. In particular, needles from TN had the highest resorption efficiency for $\mathrm{K}(96 \%)$, while the highest resorption for $\mathrm{P}(88 \%)$ was found for TB. As an average for permafrost terrain, nutrient resorption increased from $\mathrm{K}>\mathrm{P}>\mathrm{N}(84,76$ and $75 \%$, respectively). Among sites, mean nutrient resorption decreased in the order TN $>$ TV $>$ TB $>$ TS $(85,82,79$ and $72 \%$, respectively). As a result of the high resorption, nutrient losses via needle litter only amounted to $19-25 \%$ of litter N, $12-47 \%$ of its $\mathrm{P}$, and $5-27 \%$ of its K.

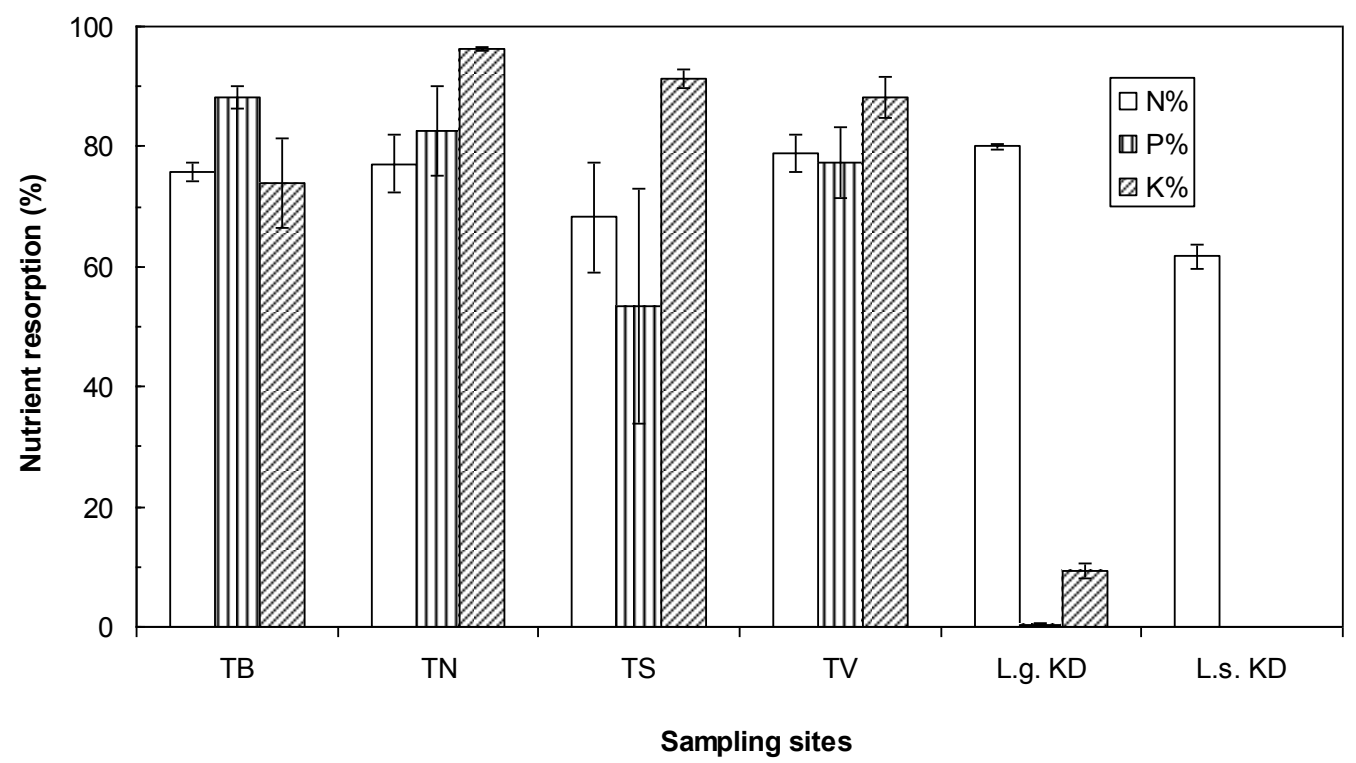

Figure 5. Intra- and inter-species variation of nutrient resorption efficiency of larch species from permafrost-affected (Tura) and permafrost-free (Krasnoyarsk) sites. Resorption of P and K is not available for L. sibirica (L.s. KD) as these elemental concentrations were not measured in senesced needles. Means and standard deviation of three replicates. 


\section{Discussion}

\subsection{Nutrient Status of Larch Improves with Active Layer Depth}

Our study along a gradient in the permafrost regime in Central Siberia showed that the nutritional status of larch trees strongly improved with a deepening of the active layer. The concomitant increase in tree productivity strongly suggests that the accelerated nutrient cycling with permafrost melt will likely contribute to an increasing productivity of larch stands in Siberia.

The mass-based concentrations of major nutrients in needles of Larix spp. in the mid-growing season observed in this study are in the lower range of reported values for Eurasia and Northern America $[5,9,13,26]$ (Figure 6). At the permafrost site at Tura, concentrations of N, P, and K in mature needles were $50 \%$ less than the optimum contents of major nutrients in larch needles $(2.1-2.6 \%$ for $\mathrm{N}, 0.3-0.6 \%$ for $\mathrm{P}$, and $0.9-2.0 \%$ for $\mathrm{K}$ ) reported by [13]. Along the gradient in the permafrost regime, the macronutrient concentrations in larch foliar biomass increased with increasing active layer depth, reflecting improving site conditions (site fertility index or "bonitet" in the Russian system). This increase was also reflected in the higher productivity of larches under favorable conditions, strongly suggesting that improved nutrient availability contributes to growth enhancement with increasing depth of the active layer.

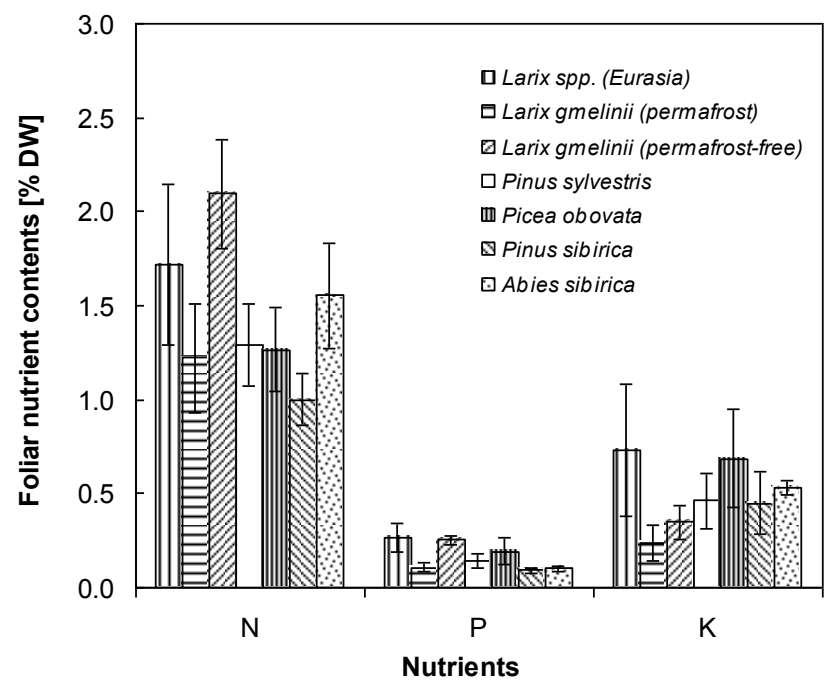

Figure 6. Mass-based concentrations of macronutrients in the foliage of main conifers of Siberia during the mid-growing season [13] compared with L. gmelinii collected at permafrost-affected and permafrost-free sites in this study.

Our data also suggest a threshold level of nutrient content in mature larch needles from this environment (ca. 1\% for $\mathrm{N}$ ), below which trees are likely to decline. On the other hand, larches from all permafrost-affected sites have a relatively narrow range of nutrient concentrations in foliage (e.g., 1.0-1.6\% N) despite a 10-fold difference in overall standing stock and 25-fold difference of needle biomass between stands with a shallow and a deep active layer depth. This pattern implies that an improving nutrient availability in the soil is rather reflected in aboveground biomass increment and in total nutrient uptake than in increased foliar nutrient concentrations. The gradient in nutrient availability among sites is probably also reflected in $C$ allocation among below- and aboveground biomass. For our study region, Kajimoto et al. [37] reported that larch trees growing on the poorly-drained and colder soils of TB had a two-fold higher root-to-shoot ratio (1.13) in comparison to sites with a deeper active layer depth (i.e., <0.5). Such patterns are likely explained by an increasing competition belowground for accessible resources within a limited soil volume. 
Foliar stoichiometric ratios like N:P or C:N are reported to be good predictors of the nutritional state of plants in nutrient-limited environments [9,25]. At the plant level, N:P ratios of $<14$ and $>16$ correspond to N- and P-limited biomass production, respectively, as demonstrated by fertilization experiments [17,25,38]. However, the Eurasian data set for Larix needles by Girs [13] shows average $\mathrm{N}: P$ ratios of 6.5 , which suggests a general $\mathrm{N}$ limitation of larch growth throughout Eurasia. In our study, N:P ratios increased from four to six in juvenile needles to 10 later in the growing season (Table 3), indicating that Larix is principally $\mathrm{N}$ limited but to a lesser extent than in other regions of Eurasia. The very small N:P ratio early in the season might not be indicative of $\mathrm{N}$ limitation as $\mathrm{N}$ concentrations were very high, with values of $3 \%$. Interestingly, N-P ratios of the various sites within the permafrost region were very similar, suggesting that they have similar physiological traits and/or adaptation to cold soils.

\section{2. ${ }^{15} \mathrm{~N}$ Enrichment of Needles on Warmer Soils}

In larch stands of the studied permafrost region, N-pools varied from 0.2 to $1.0 \mathrm{Mg} \mathrm{N} / \mathrm{ha}$ in the organic soil layers [39], and an additional 3.3-5.2 Mg N/ha (this study) or up to $6.6 \mathrm{Mg} \mathrm{N} / \mathrm{ha}$ [40] in the mineral soil. Overall, the soil nitrogen pool usually exceeds $80 \%$ of the total ecosystem $\mathrm{N}$ pool in northern taiga [41]. Nevertheless, the availability of $\mathrm{N}$ and other nutrients for plants is limited due to small net $\mathrm{N}$ mineralization rates and plant growth largely depends on nutrient supply provided by ectomycorrhizal (ECM) fungi. Hobbie and Högberg [42] reported that mycorrhizal fungi provided $61-86 \%$ of the N-uptake for arctic tundra plants and for Alaskan permafrost terrain and Mayor et al. [43] estimated that ECM-derived N may constitute $8-92 \%$ of black spruce annual demand. Our results showed that larches growing in deep active layers with smaller total soil $\mathrm{N}$ stocks had higher foliar mass-based $\mathrm{N}$ concentrations and elevated $\delta^{15} \mathrm{~N}$ values. The strong enrichment with ${ }^{15} \mathrm{~N}$ in 'warmer' soils is indicative of an improved $\mathrm{N}$ supply [21,44]. A soil warming study at the alpine treeline with Larix suggests that increased $\delta^{15} \mathrm{~N}$ values are related to increased contents of mineral $\mathrm{N}$ in the soil, which reduced the need to take up $\mathrm{N}$ via mycorrhiza, in turn inducing ${ }^{15} \mathrm{~N}$ depletion in foliar biomass [45]. Alternatively, ${ }^{15} \mathrm{~N}$ enrichment may reflect $\mathrm{N}$-uptake from the deeper unfrozen soils which are enriched in $\mathrm{N}$ compared to the topsoil. The TB site was an exception in this pattern, with larches having higher foliar $\delta^{15} \mathrm{~N}$ values (ca. - $5.0 \%$ ) in comparison to the north-facing slope. One reason could be a decreasing abundance of ECM fungi in bogs, because they are sensitive to waterlogging and P-limitation [46] and as a consequence, larches in bogs rely more strongly on mineral $\mathrm{N}$. Except for the peat bog, $\mathrm{N}$ concentrations and $\delta^{15} \mathrm{~N}$ values correlated positively with larch productivity, which strongly suggests that an improving $\mathrm{N}$ nutritional status with increasing depth of the active layer is an important driver of better tree growth in warmer soils.

\subsection{Strong Seasonal Dynamics in Nutrient Concentrations and ${ }^{13} \mathrm{C}$}

At the permafrost site, nutrient concentration showed very strong seasonal variation with a several-fold decline throughout the growing season. The highest concentrations of foliar $\mathrm{N}, \mathrm{P}$, and $\mathrm{K}$ at all permafrost-affected sites were found in the early growing season, when the needles were first produced. A similar pattern was reported for the same elements in Siberian larch from Mongolia [9] and micronutrients (i.e., $\mathrm{Cu}, \mathrm{B}, \mathrm{Na}, \mathrm{Ni}$ etc.) in the same habitats for Gmelin's larch [32]. Elevated $\mathrm{N}, \mathrm{P}$, and $\mathrm{K}$ concentrations are indicators of active metabolic processes and high photosynthetic rates (i.e., high Rubisco content), as well as high energy requirements and protein synthesis [47]. In our study, the initial peak in nutrient concentrations was much less pronounced at the warmer permafrost-free site, suggesting that low temperatures are reinforcing this pattern. In support of this conclusion, Woods et al. [48] as well as Reich and Oleksyn [26] interpret the enrichment in foliar nutrients (mainly $\mathrm{N}$ and $\mathrm{P}$ ) as an adaptation by plants to enhance metabolic activity and growth rates under low temperatures [26,48]. Remarkably, the highest concentrations of macro- and micronutrients in larch foliage of permafrost-affected habitats occurred when the soil remained frozen and the uptake of nutrients from the soil was very limited. This indicates that the development of the photosynthetic 
apparatus in the early season is based on the pool of nutrients accumulated during the previous growing season and stored throughout the winter. The substantial translocation of nutrients in larch needles from year to year in permafrost terrains is supported by our findings of a strong resorption of nutrients in the permafrost sites but not on permafrost-free soils. Resorption is a key mechanism for deciduous plants to avoid losses of essential nutrients in litterfall [25]. It is hypothesized to be particularly high at nutrient-poor sites [17], supplying a considerable proportion of a tree's nutrient requirement for new biomass production [25,26]. The recycling of nutrients is even more essential for trees that renew their foliage on an annual basis and thus require large quantities of $C$ and nutrients to construct new photosynthetic biomass. Our results show that permafrost is even fostering nutrient resorption to support a tree's life early in the following year.

We observed that juvenile needles were enriched in ${ }^{13} \mathrm{C}$ compared to mature needles, which could indicate that the storage carbohydrates (e.g., starch) that are generally more enriched in ${ }^{13} \mathrm{C}$ served as an essential $C$ source in early developmental stages [9]. However, higher photosynthetic rates (and respective reduction of $c_{i} / c_{a}$ ratio) under high foliar $\mathrm{N}$ and $\mathrm{P}$ levels may also lead to elevated ${ }^{13} \mathrm{C}$ in early season foliage of larch.

With the progression of the growing season, bulk foliar ${ }^{13} \mathrm{C}$ decreased, probably reflecting an increase in the proportion of current photoassimilates used for needle growth [9]. In addition, nutrient concentrations decreased strongly, which is typical for $\mathrm{N}$ in deciduous angiosperm species and evergreen conifers [13,49]. Much less marked changes are usually observed for foliar P and K, although some authors report similar dynamics to $\mathrm{N}$ [50]. Likewise, nutrient concentrations in larch needles from the permafrost site changed predictably as a function of needle development and the needle $\mathrm{C}: \mathrm{N}, \mathrm{C}: \mathrm{P}$, and $\mathrm{C}: \mathrm{K}$ ratios increased significantly with needle maturation. Firstly, the foliar nutrients become diluted by increasing quantities of C-rich cell-wall material [27]. Higher lignification of needle tissues in nutrient-poor environments may further enrich needles in C-rich aromatic compounds [51], which might be indicated by the findings of lower $\delta^{13} \mathrm{C}$ values in bulk needles as lignin is generally depleted in ${ }^{13} \mathrm{C}$. Another reason reported for the decrease of nutrients during a growing season is nutrient withdrawal to active growing zones (e.g., fine roots, shoots) and/or reproductive organs of plants growing in nutrient-limited soils [49,52].

\section{Conclusions}

Our results indicate that on permafrost soils, the preservation of macronutrients by resorption during autumn and the formation of juvenile needles with very high nutrient contents and particularly low N:P ratios at the beginning of the growing season is an important mechanism by which larch trees sustain high metabolic activity early in the season, despite low air temperatures and frozen soils. Such a strategy may allow larch forests to cope with the low nutrient availability in cold soils in the short-term early in the season or even in the long-term for the entire life-span of trees, where the development of a thick soil-insulating organic layer induces a progressive nutrient limitation.

Our site comparison showed that with increasing active layer depth nutrient contents, $\delta^{15} \mathrm{~N}$ values and biomass productivity strongly increased. This pattern implies that deepening of the soil active layer increases rates of nutrient cycling in soils, which in turn stimulates the productivity of larch forests over vast permafrost regions of Siberia. Consequently, permafrost degradation by climatic warming may enhance the currently weak sink of atmospheric $\mathrm{CO}_{2}$ in these landscapes (e.g., $\mathrm{NEP}=76 \mathrm{gC} / \mathrm{m}^{2} /$ a reported for Tura site [11]) if it is not outbalanced by increased $\mathrm{CO}_{2}$ losses from soil organic matter, which is so far locked in permafrost. An increased NEP can be expected as long as tree productivity is supported by an enhanced nutrient availability. Closely similar foliar $\mathrm{N}: \mathrm{P}$ ratios observed in different sites of the permafrost region, contrasted with $\mathrm{N}: \mathrm{P}$ ratio variation in permafrost-free sites, suggests site-specific metabolic traits of Gmelin's larch and/or site-specific nutrient availability under local climatic and soil conditions. Along with the site-specific resorption efficiency for these elements, the observed patterns indicate that in permafrost terrains of the Central Siberian Plateau, not only N, but also P and K, may currently limit tree growth. In particular, the higher 
efficacy of $\mathrm{P}$ and $\mathrm{K}$ resorption in poor and cold habitats reflects the plasticity of larches to maintain growth in a severe environment.

Supplementary Materials: The following are available online at http:/ /www.mdpi.com/1999-4907/9/6/314/s1, Table S1: Site- and fraction-specific allometry equations, Table S2: Statistical significance of the linear mixed model testing the effects of active layer thickness and time (Julian day in the growing season) on element concentrations and isotopic composition.

Author Contributions: A.S.P. originally formulated the idea. A.S.P., A.V.K., O.S.P., and O.V.M. conceived, designed, and performed the experiments. A.S.P., F.H., O.S.P., M.P.P., J.V., and W.H.M. analysed the data and wrote the manuscript.

Acknowledgments: This study has been was supported by the Russian Science Foundation No. 14-24-00113, Russian Fund for Basic Research No. 16-04-00796, French National Programme INSU (EC2CO, Environnement Côtier PNEC), by GDRI CAR-WET-SIB, and by US National Science Foundation DEB 15-56603.

Conflicts of Interest: The authors declare no conflict of interest.

\section{References}

1. Goodale, C.L.; Apps, M.J.; Birdsey, R.A. Forest carbon sinks in the Northern Hemisphere. Ecol. Appl. 2002, 12, 891-899. [CrossRef]

2. Gower, S.T.; Richards, J.H. Larches: Deciduous conifers in an evergreen world. BioScience 1990, 40, 818-826. [CrossRef]

3. Vedrova, E.F.; Pleshikov, F.I.; Kaplunov, V.Y. Net ecosystem production of boreal Larch ecosystems on the Yenisei transect. Mitig. Adapt. Strat. Glob. Chang. 2006, 11, 173-190. [CrossRef]

4. Abaimov, A.P. Geographical Distribution and Genetics of Siberian Larch Species. In Permafrost Ecosystems: Siberian Larch Forests; Osawa, A., Kajimoto, T., Zyryanova, O.A., Matsuura, Y., Wein, R., Eds.; Springer: Dordrecht, The Netherlands, 2010; pp. 41-58, ISBN 978-1-4020-9692-1.

5. Kloeppel, B.D.; Gower, S.T.; Triechel, I.W.; Kharuk, S. Foliar carbon isotope discrimination in Larix species and sympatric evergreen conifers: A global comparison. Oecologia 1998, 114, 153-159. [CrossRef] [PubMed]

6. Vygodskaya, N.N.; Milyukova, I.; Varlagin, A.; Tatarinov, F.; Sogachev, A.; Kobak, K.I.; Desyatkin, R.; Bauer, G.; Hollinger, D.Y.; Kelliher, F.M.; et al. Leaf conductance and $\mathrm{CO}_{2}$ assimilation of Larix gmelinii growing in an eastern Siberian boreal forest. Tree Physiol. 1997, 17, 607-615. [CrossRef] [PubMed]

7. Sugimoto, A.; Yanagisawa, N.; Naito, D.; Fujita, N.; Maximov, T.C. Importance of permafrost as a source of water for plants in east Siberian taiga. Ecol. Res. 2002, 17, 493-503. [CrossRef]

8. Alexeev, V.A.; Birdsey, R.A.; Stakanov, V.D.; Korotkov, I. Carbon in vegetation of Russian forests: Methods to estimate storage and geographical distribution. Water Air Soil Pollut. 1995, 82, 271-282. [CrossRef]

9. Li, S.-G.; Tsujimura, M.; Sugimoto, A.; Davaa, G.; Oyunbaatar, D.; Sugita, M. Temporal variation of $\delta^{13} \mathrm{C}$ of larch leaves from a montane boreal forest in Mongolia. Trees 2007, 21, 479-490. [CrossRef]

10. Dolman, A.J.; Maximov, T.C.; Moors, E.J.; Maximov, A.P.; Elbers, J.A.; Kononov, A.V.; Waterloo, M.J.; van der Molen, M.K. Net ecosystem exchange of carbon dioxide and water of far eastern Siberian Larch (Larix cajanderii) on permafrost. Biogeosciences 2004, 1, 133-146. [CrossRef]

11. Nakai, Y.; Matsuura, Y.; Kajimoto, T.; Abaimov, A.P.; Yamamoto, S.; Zyryanova, O.A. Eddy covariance $\mathrm{CO}_{2}$ flux above a Gmelin larch forest on continuous permafrost in Central Siberia during a growing season. Theor. Appl. Climatol. 2008, 9, 133-147. [CrossRef]

12. Sidorova, O.V.; Siegwolf, R.; Saurer, M.; Shashkin, A.V.; Knorre, A.A.; Prokushkin, A.S.; Vaganov, E.A.; Kirdyanov, A.V. Do centennial tree-ring and stable isotope trends of Larix gmelinii (Rupr.) indicate increasing water shortage in the Siberian north? Oecologia 2009, 161, 25-835. [CrossRef] [PubMed]

13. Girs, G.I. Accumulation of Nitrogen, Phosphorus and Potassium by Soil-Forming Species of Russia; V.N. Sukachev Institute of Forest SB RAS: Krasnoyarsk, Russia, 1996. (In Russian)

14. Schulze, E.D.; Schulze, W.; Kelliher, F.M.; Vygodskaya, N.N.; Ziegler, W.; Kobak, K.I.; Koch, H.; Arneth, A.; Kusnetsova, W.A.; Sogachev, A.; et al. Aboveground biomass and nitrogen nutrition in a chronosequence of pristine Gmelin's Larix stands in Eastern Siberia. Can. J. For. Res. 1995, 25, 943-960. [CrossRef]

15. Kajimoto, T.; Matsuura, Y.; Osawa, A.; Abaimov, A.P. Size-mass allometry and biomass allocation of two larch species growing on the continuous permafrost region in Siberia. For. Ecol. Manag. 2006, 22, 314-325. [CrossRef] 
16. Vitousek, P.M.; Howarth, R.W. Nitrogen limitation on land and in the sea: How can it occur? Biogeochemistry 1991, 13, 87-115. [CrossRef]

17. Aerts, R.; Chapin, F.S., III. The mineral nutrition of wild plants revisited: A re-evaluation of processes and patterns. Adv. Ecol. Res. 2000, 30, 1-67. [CrossRef]

18. Lambers, H.; Shaver, G.; Raven, J.A. N- and P-acquisition change as soils age. Trends Ecol. Evol. 2008, 23, 95-103. [CrossRef] [PubMed]

19. Wang, Y.P.; Law, R.M.; Pak, B. A global model of carbon, nitrogen and phosphorus cycles for the terrestrial biosphere. Biogeosciences 2009, 6, 9891-9944. [CrossRef]

20. Martinelli, L.A.; Piccolo, M.C.; Townsend, A.R.; Vitousek, P.M.; Cuevas, E.; McDowell, W.; Robertson, G.P.; Santos, O.C.; Treseder, K. Nitrogen stable isotopic composition of leaves and soil: Tropical versus temperate forests. Biogeochemistry 1999, 46, 45-65. [CrossRef]

21. Craine, J.M.; Elmore, A.J.; Aidar, M.P.M.; Bustamante, M.; Dawson, T.E.; Hobbie, E.A.; Kahmen, A.; Mack, M.C.; McLauchlan, K.K.; Michelsen, A.; et al. Global patterns of foliar nitrogen isotopes and their relationships with climate, mycorrhizal fungi, foliar nutrient concentrations, and nitrogen availability. New Phytol. 2009, 183, 980-992. [CrossRef] [PubMed]

22. Qu, L.Y.; Makoto, K.; Choi, D.S.; Quoreshi, A.M.; Koike, T. The role of ectomycorrhiza in boreal forest ecosystem. In Permafrost Ecosystems: Siberian Larch Forests; Osawa, A., Kajimoto, T., Zyryanova, O.A., Matsuura, Y., Wein, R., Eds.; Springer: Dordrecht, The Netherlands, 2010; pp. 413-426, ISBN 978-1-4020-9692-1.

23. Michelsen, A.; Quarmby, C.; Sleep, D.; Jonasson, S. Vascular plant ${ }^{15} \mathrm{~N}$ natural abundance in heath and forest tundra ecosystems is closely correlated with presence and type of mycorrhizal fungi in roots. Oecologia 1998, 115, 406-418. [CrossRef] [PubMed]

24. Hobbie, E.A.; Ouimette, A.P. Controls of nitrogen isotope patterns in soil profiles. Biogeochemistry 2009, 95, 355-371. [CrossRef]

25. Aerts, R. Nutrient resorption from senescing leaves of perennials: Are there general patterns? J. Ecol. 1996, 4, 597-608. [CrossRef]

26. Killingbeck, K.T. Nutrients in senesced leaves: Keys to the search for potential resorption and resorption proficiency. Ecology 1996, 77, 1716-1727. [CrossRef]

27. Reich, P.B.; Oleksyn, J. Global patterns of plant leaf $\mathrm{N}$ and $\mathrm{P}$ in relation to temperature and latitude. Proc. Natl. Acad. Sci. USA 2004, 101, 11001-11006. [CrossRef] [PubMed]

28. Matsuura, Y.; Hirobe, M. Soil carbon and nitrogen, and characteristics of soil active layer in Siberian permafrost region. In Permafrost Ecosystems: Siberian Larch Forests; Osawa, A., Kajimoto, T., Zyryanova, O.A., Matsuura, Y., Wein, R., Eds.; Springer: Dordrecht, The Netherlands, 2010; pp. 149-164, ISBN 978-1-4020-9692-1.

29. Eckstein, R.L.; Karlsson, P.S.; Weih, M. Leaf life span and nutrient resorption as determinants of plant nutrient conservation in temperate-arctic regions. New Phytol. 1999, 143, 177-189. [CrossRef]

30. Prokushkin, A.S.; Tokareva, I.V.; Prokushkin, S.G.; Abaimov, A.P.; Guggenberger, G. Fluxes of dissolved organic matter in larch forests in the Cryolithozone of Central Siberia. Rus. J. Ecol. 2008, 39, 151-159. [CrossRef]

31. Wild, B.; Schnecker, J.; Knoltsch, A.; Takriti, M.; Mooshammer, M.; Gentsch, N.; Mikutta, R.; Eloy Alves, R.J.; Gittel, A.; Lashchinskiy, N.; et al. Microbial nitrogen dynamics in organic and mineral soil horizons along a latitudinal transect in western Siberia. Glob. Biogeochem. Cycles 2015, 29, 567-582. [CrossRef] [PubMed]

32. Viers, J.; Prokushkin, A.S.; Pokrovsky, O.S.; Auda, Y.; Kirdyanov, A.V.; Beaulieu, E.; Zouiten, C.; Oliva, P.; Dupre, B. Seasonal and spatial variability of elemental concentrations in boreal forest larch foliage of Central Siberia on continuous permafrost. Biogeochemistry 2013, 113, 435-449. [CrossRef]

33. Larjavaara, M.; Berninger, F.; Palviainen, M.; Prokushkin, A.; Wallenius, T. Post-fire carbon and nitrogen accumulation and succession in Central Siberia. Sci. Rep. 2017, 12776. [CrossRef] [PubMed]

34. Wood. Method of Selection of Model Trees and Logs for Determination of Physical and Mechanical Properties of Wood Plantations. State Standard of the USSR (ГOCT 16483.6-80). 1981. Available online: http:/ / docs. cntd.ru/document/1200014947 (accessed on 4 April 2014).

35. Cook, E.R.; Kairiukstis, L.A. Methods of Dendrochronology. Application in Environmental Sciences; Springer: Dordrecht, The Netherlands, 1990. 
36. Farquhar, G.D.; Ehleringer, R.; Hubic, K.T. Carbon isotope discrimination and photosynthesis. Ann. Rev. Plant Physiol. Plant Mol. Biol. 1989, 40, 503-537. [CrossRef]

37. Kajimoto, T.; Matsuura, Y.; Sofronov, M.A.; Volokitina, A.V.; Mori, S.; Osawa, A.; Abaimov, A.P. Above- and belowground biomass and net primary productivity of a Larix gmelinii stand near Tura, Central Siberia. Tree Physiol. 1999, 19, 815-822. [CrossRef] [PubMed]

38. McGroddy, M.E.; Daufresne, T.; Hedin, L.O. Scaling of C:N:P stoichiometry in forests worldwide: Implications of terrestrial Redfield-type ratios. Ecology 2004, 85, 2390-2401. [CrossRef]

39. Prokushkin, A.S.; Knorre, A.A.; Kirdyanov, A.V.; Schulze, E.D. Productivity of mosses and organic matter accumulation in the litter of sphagnum larch forest in the permafrost zone. Rus. J. Ecol. 2006, 37, $225-232$. [CrossRef]

40. Tokuchi, N.; Hirobe, M.; Kondo, K.; Arai, H.; Hobara, S.; Fukushima, K.; Matssura, Y. Soil nitrogen dynamics in larch ecosystems. In Permafrost Ecosystems: Siberian Larch Forests; Osawa, A., Kajimoto, T., Zyryanova, O.A., Matsuura, Y., Wein, R., Eds.; Springer: Dordrecht, The Netherlands, 2010; pp. 229-244, ISBN 978-1-4020-9692-1.

41. Shugaley, L.S.; Vedrova, E.F. Nitrogen pool in northern taiga larch forests of Central Siberia. Biol. Bull. 2004, 31, 200-208. [CrossRef]

42. Hobbie, E.A.; Högberg, P. Nitrogen isotopes link mycorrhizal fungi and plants to nitrogen dynamics. New Phytol. 2012, 196, 67-82. [CrossRef] [PubMed]

43. Mayor, J.R.; Schuur, E.A.G.; Mack, M.C.; Hollingsworth, T.N.; Baath, E. Nitrogen isotope patterns in Alaskan black spruce reflect organic nitrogen sources and the activity of ectomycorrhizal fungi. Ecosystems 2012, 15, 819-831. [CrossRef]

44. Högberg, M.N.; Briones, M.J.I.; Keel, S.G.; Metcalfe, D.B.; Campbell, C.; Midwood, A.J.; Thornton, B.; Hurry, V.; Linder, S.; Nasholm, T.; et al. Quantification of effects of season and nitrogen supply on tree below-ground carbon transfer to ectomycorrhizal fungi and other soil organisms in a boreal pine forest. New Phytol. 2010, 187, 485-493. [CrossRef] [PubMed]

45. Dawes, M.A.; Schleppi, P.; Hagedorn, F. The fate of nitrogen inputs in a warmer alpine treeline ecosystem: A ${ }^{15} \mathrm{~N}$ labelling study. J. Ecol. 2017, 105, 1723-1737. [CrossRef]

46. Wurzburger, N.; Hartshorn, A.S.; Hendrick, R.L. Ectomycorrhizal fungal community structure across a bog-forest ecotone in southeastern Alaska. Mycorrhiza 2004, 14, 383-389. [CrossRef] [PubMed]

47. Reich, P.B.; Oleksyn, J.; Wright, I.J. Leaf phosphorus influences the photosynthesis-nitrogen relation. A cross-biome analysis of 314 species. Oecologia 2009, 160, 207-212. [CrossRef] [PubMed]

48. Woods, H.A.; Makino, W.; Cotner, J.B.; Hobbie, S.; Harrison, J.F.; Acharya, K.; Elser, J.J. Temperature and the chemical composition of poikilothermic organisms. Funct. Ecol. 2003, 17, 237-245. [CrossRef]

49. Prokushkin, S.G. Mineral Nutrition of Pine; Nauka: Novosibirsk, Russia, 1982. (In Russian)

50. Lukina, N.V. Seasonal variation in chemical composition of Pinus sylvestris L. needles in the Kola Peninsula. Lesovedenie 1996, 1, 41-53. (In Russian)

51. Glynn, C.; Herms, D.A.; Orians, C.M.; Hansen, R.C.; Larsson, S. Testing the growth-differentiation balance hypothesis: Dynamic responses of willows to nutrient availability. New Phytol. 2007, 176, 623-634. [CrossRef] [PubMed]

52. Bazilevich, N.I.; Titlyanova, A.A. Biotic Turnover on Five Continents. Element Exchange Processes in Terrestrial Natural Ecosystems; Publishing House SB RAS: Novosibirsk, Russia, 2008; ISBN 978-5-7692-0941-3. (In Russian)

(C) 2018 by the authors. Licensee MDPI, Basel, Switzerland. This article is an open access article distributed under the terms and conditions of the Creative Commons Attribution (CC BY) license (http:/ / creativecommons.org/licenses/by/4.0/). 